\title{
Bacterioplankton dynamics and organic carbon partitioning in the lower Hudson River estuary
}

\author{
Sergio A. Sañudo-Wilhelmy*, Gordon T. Taylor \\ Marine Sciences Research Center, State University of New York, Stony Brook, New York 11794-5000, USA
}

\begin{abstract}
Surface water samples collected at 10 stations in April 1996 along the entire salinity gradient of the Hudson River estuary were fractionated into particulate (POC), dissolved (DOC; $<0.45 \mu \mathrm{m}$ ), high molecular weight ( $\mathrm{HMWOC} ; 10 \mathrm{kDa}-0.45 \mu \mathrm{m}$ ), and low molecular weight (LMWOC; $<10 \mathrm{kDa}$ ) organic carbon. Bacterial concentrations, production and specific growth rates were also determined at each location. While HMWOC ( 6 to $26 \mu \mathrm{M}$ ) exhibited nonconservative removal relative to ideal dilution of river and seawater along the estuary, DOC (176 to $324 \mu \mathrm{M})$ showed a nonconservative excess along this salinity gradient. These contrasting distributions suggest that the majority of DOC was exported to the ocean and consisted of low lability material, while a reactive fraction of HMWOC was removed during estuarine mixing. Bacterial abundances (5 to $16 \times 10^{8}$ cells $\left.\mathrm{l}^{-1}\right)$, production $\left(3.4\right.$ to $\left.28.7 \mu \mathrm{g} \mathrm{C}^{-1} \mathrm{~d}^{-1}\right)$, and specific growth rates $\left(0.09\right.$ to $\left.0.66 \mathrm{~d}^{-1}\right)$ varied significantly along the salinity gradient. These variables were positively correlated with algal standing stocks (chlorophyll a) and even more coherent with HMWOC distributions. In contrast, bacterial metabolism varied independently of POC, DOC, and LMWOC concentrations. Therefore, while HMWOC accounted for $<10 \%$ of the DOC, this pool appeared to be very dynamic, possibly due to bacterial degradation. However, mass balance estimates indicate that bacterial uptake could remove at most $30 \%$ of the HMWOC. suggesting that abiotic processes such as flocculation are probably the major removal mechanism of HMW organic matter within the estuary. Lastly, contrary to previous results from the tidal freshwater section of the Hudson, strong coherence between primary and secondary production and the nonconservative excesses of DOC found in the lower estuary suggest that carbon and bacterial dynamics can vary qualitatively along different reaches of this river.
\end{abstract}

KEY WORDS: Bacterioplankton - Organic carbon - Hudson River estuary

\section{INTRODUCTION}

The cycling of terrigenous organic carbon in rivers and its subsequent export to oceans are determined by heterogeneous estuarine processes (e.g. flocculation, precipitation, photolysis, microbial degradation, food web interactions, etc.). However, the conservative distributions and/or nonconservative excess of dissolved organic carbon (DOC) observed in estuaries (Mantoura \& Woodward 1983, Aminot et al. 1990, Findlay et al. 1991a, 1992, Howarth et al. 1992, Dai et al. 1995, Powell et al. 1996) suggest that the bulk of allochthonous carbon is not involved in those processes and is mainly

\footnotetext{
•E-mail: ssanudo@notes.cc.sunysb.edu
}

composed of relatively unreactive and biologically recalcitrant materials. In order to understand processes affecting regional and global carbon budgets, it is necessary to determine the fates of different organic carbon fractions in natural waters. For example, Fox (1983) showed that, while salt-induced flocculation is a major mechanism of removal of humic acids during estuarine mixing, this removal is not reflected in the DOC pool because humic compounds represent only a small fraction of the DOC.

One large uncertainty in the study of carbon cycling is the identity of the pool(s) supporting the high bacterial biomass and activity observed in estuaries (Coffin \& Sharp 1987, Howarth et al. 1992, Hoch \& Kirchman 1993, Connolly \& Coffin 1995). Clearly, in severely light-limited estuaries, the observed low levels 
of in situ primary production are insufficient to support bacterial energy demands through fluxes driven by exudation and mortality. In fact, some estuaries, such as the tidal freshwater section of the Hudson River estuary and the Amazon River (Richey et al. 1990, Findlay et al. 1991b, 1992, Howarth et al. 1992, Benner et al. 1995), are net heterotrophic, i.e. respiration and bacterial net production (BNP) always exceed in situ primary production. Therefore, microbial metabolism must be subsidized by allochthonous carbon sources.

Microheterotrophic carbon demand has the potential to greatly influence the composition and amount of organic carbon delivered to the ocean. Results from a few laboratory studies have suggested that high molecular weight organic carbon ( $\mathrm{HMWOC}_{\mathrm{i}}>10 \mathrm{kDa}$ ) in natural DOC pools can be more available to bacteria than the low molecular weight (LMWOC; $<10 \mathrm{kDa}$ ) fraction (e.g. Tranvik 1990). The bioreactivity of HMWOC over LMWOC pools has also been observed in field studies of the Amazon River system and the Gulf of Mexico (Benner et al. 1995, Amon \& Benner 1996). If this is the general case, then HMWOC may play a more important role in supporting bacterial metabolism and in subsequent trophic transfer than previously believed. Considering its small contribution to the total carbon pool $k 20 \%$ of the total dissolved; Whitehouse et al. 1989, Guo et al. 1994, Dai et al. 1995), the HMWOC pool is potentially far more dynamic than particulate or dissolved pools. However, even if bacterial decomposition removes all HMWOC, this removal will not necessarily be apparent in the distribution of the much larger DOC pool.

To better understand bacterial interactions with native pools of organic carbon, we examined size-fractionated (particulate, dissolved, LMW, and HMW) organic carbon concentrations and bacterioplankton dynamics (abundance, production and growth rates) at 10 locations across the entire salinity gradient of the Hudson River estuary. The area of study included the rural, forested catchments in the tidal, freshwater region of the estuary as well as the marine end-member in the heavily populated upper bay. This sampling scheme was designed to allow us to determine the relative importance of different types and sources of DOM to bacterial metabolism.

The Hudson River estuary presents ideal conditions to establish the relationship between bacterial activity and HMWOC. It is known that the tidal, freshwater section of the Hudson River is net heterotrophic, and bacterial biomass and production appear to be decoupled from primary production (Findlay et al. 1991b). Therefore, BNP must be subsidized, in large part, by allochthonous input of organic matter into the system (Findlay et al. 1991 a, 1992, Howarth et al. 1992). The conservative distribution of DOC during transport along this reach of the Hudson River further suggests that the majority of organic matter is refractory and that high bacterial abundance and production is supported by a relatively small, and 'unidentified' labile organic carbon pool (Findlay et al. 1992, Howarth et al. 1992). Results presented here suggest that, indeed, preferential bacterial utilization of HMWOC over the abundant LMWOC fraction is apparent along the estuarine reach of this river. However, contrary to previous results obtained upriver, we found a nonconservative excess of DOC with respect to ideal dilution of river and seawater, and a strong coherence between primary and secondary production in the lower estuary. These findings suggest that carbon and bacterial dynamics can vary qualitatively among different reaches of large rivers.

\section{MATERIALS AND METHODS}

Sampling. Surface water samples were collected during the period April 3 to 5, 1996 at 10 locations in the Hudson River estuary, under high river discharge conditions. The geographical distribution of the sampling sites covered the tidal, freshwater section of the river (Newburgh, New York, USA) to the Atlantic Ocean (Sandy Hook, New Jersey; about $120 \mathrm{~km}$ ) (Fig. 1). Because bacterial activity varies as a function of water temperature, samples were collected in the spring when this effect should be minimal, due to uniformly low water temperatures typically observed (Ashizawa \& Cole $1994)$. Surface waters, in fact, only varied from 5.1 to $6.4^{\circ} \mathrm{C}$ during this study. In contrast, allochthonous inputs of HMW organic matter from the watershed are expected to be greatest under high flow conditions during spring (Findlay et al. 1991a, Howarth et al. 1992).

Organic carbon inventories. Three independent samples were collected from a depth of $1 \mathrm{~m}$ at each location for POC and DOC analysis by a trace metalclean pumping system. POC was analyzed on suspended matter retained on precombusted, $13 \mathrm{~mm}$ GF/F glass-fiber filters, and total DOC was determined in filtered $\left(<0.45 \mu \mathrm{m}_{i}\right.$ polypropylene capsule filters; MSI Inc.) samples. A $20 \mathrm{l}$ water sample was also collected at each location and filtered $(<0.45 \mu \mathrm{m})$ for size fractionation by ultrafiltration. This sample was stored in acid-cleaned $20 \mathrm{l}$ dark Teflon bag containers, refrigerated immediately, and ultrafiltered within $24 \mathrm{~h}$ of collection in an acid-cleaned Filtron cross-flow filtration system (10 kDa) modified for trace metals analysis (Sañudo-Wilhelmy et al. 1996). In order to avoid breakthrough and/or diffusion of organic carbon from the retentate to the ultrafiltrate (Buesseler et al. 1996, Wen et al. 1996), samples were preconcentrated only to a factor of 7.5. Similar concentration factors ( 7 to 10 ) have also been used to isolate HMWOC in other estuaries (Powell et al. 1996). 


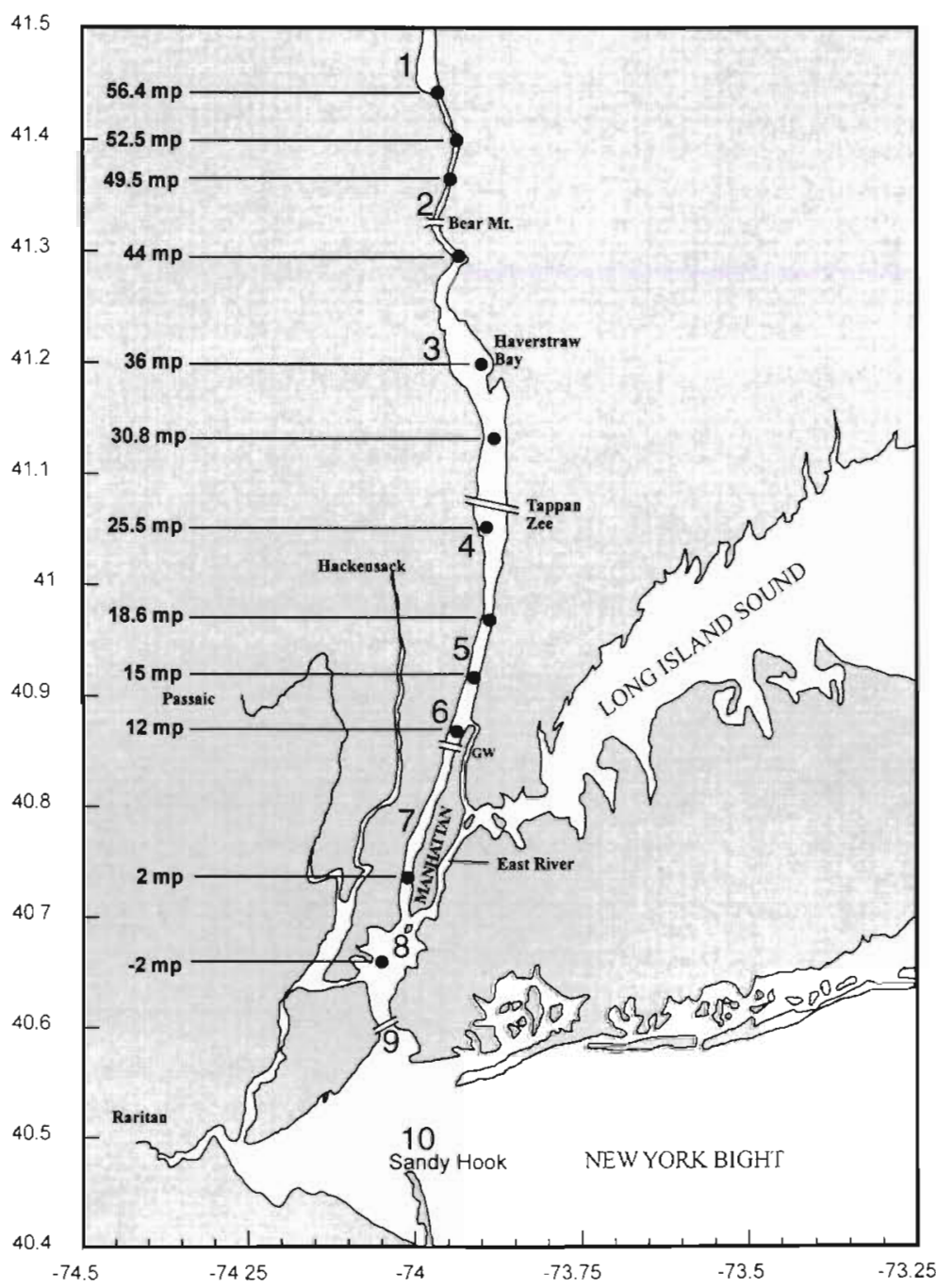

Fig. 1 Map of the Hudson River estuary showing the area of study and sampling locations
Ultrafiltration cleaning and operating protocols have been reported elsewhere (e.g. Whitehouse et al. 1990, Sañudo-Wilhelmy et al. 1996). The consistency of the ultrafiltration protocols is indicated by the high ultrafiltration recoveries (from 80 to $108 \%$ ) (Table 1). The efficiency of the cleaning protocols was also demonstrated by the analysis of ultrafiltration blanks. Organic carbon blanks for the ultrafiltration system were obtained by ultrafiltering water from a combined Milli-RO/Milli-Q Plus System (Millipore) equipped with sand, carbon and polygard prefilters. The ultrafiltration blanks were $38 \pm 22 \mu \mathrm{M}$ for the retentate and $35 \pm 21 \mu \mathrm{M}$ for the ultrafiltrate $(n=3$, mean $\pm 1 \mathrm{SD})$.

The concentrations of organic carbon in the dissolved fractions were determined by high temperature catalytic oxidation using a Shimadzu TOC-5000 Total Organic Carbon Analyzer. POC was measured in a Carlo Erba NA1500 NCS system. Dissolved phosphate, salinity, suspended particulate matter, and chlorophyll a were determined using standard methods (Strickland \& Parsons 1972).

Bacterial abundances. At each station, whole water samples $(100 \mathrm{ml})$ were preserved with $2 \%$ borate-buffered formaldehyde (final conc.) for bacterial abundance and biomass determinations. In the laboratory, standard DAPI-stained slides were prepared on dark $0.2 \mu \mathrm{m}$ Poretics polycarbonate membranes for enumeration by epifluorescence microscopy (Porter \& Feig 1980). Bacterial biomass was determined

Table 1. Dissolved (DOC), low molecular weight (LMW), high molecular weight (HMW), and particulate (POC) organic carbon concentrations $(\mu \mathrm{M})$ measured in surface waters of the Hudson River estuary in April 1996. DOC and POC are reported as the mean \pm 1 SD of 3 independent samples. LMWOC is reported as the mean \pm 1 SD of multiple analyses of the same sample

\begin{tabular}{|c|c|c|c|c|c|c|}
\hline Location & $\begin{array}{c}\text { DOC } \\
(<0.45 \mu \mathrm{m})\end{array}$ & $\begin{array}{c}\text { LMW } \\
(<10 \mathrm{kDa})\end{array}$ & $\begin{array}{c}\mathrm{HMW}^{\mathrm{a}} \\
(10 \mathrm{kDa}-0.45 \mu \mathrm{m})\end{array}$ & $\mathrm{POC}$ & $\begin{array}{c}\text { HMW/DOC } \\
(\%)\end{array}$ & $\begin{array}{c}\text { Mass balance }{ }^{b} \\
(\%)\end{array}$ \\
\hline 1. Newburgh Bridge & $261 \pm 15$ & $247 \pm 18$ & 17 & $56 \pm 12$ & 6.5 & 101.2 \\
\hline 2. Foundry Cove & $294 \pm 21$ & $291 \pm 6$ & 26 & $52 \pm 4$ & 8.9 & 107.8 \\
\hline 3. Haverstraw Bay & $295 \pm 28$ & $289 \pm 5$ & 6 & $48 \pm 2$ & 2.0 & 100.0 \\
\hline 4. Piermont & $306 \pm 30$ & $244 \pm 4$ & 10 & $63 \pm 1$ & 3.3 & 83.0 \\
\hline 5. Yonkers & $324 \pm 32$ & $263 \pm 5$ & 11 & $77 \pm 9$ & 3.4 & 85.0 \\
\hline 6. G.W. Bridge & $281 \pm 5$ & 242 & 10 & $101 \pm 8$ & 3.6 & 89.7 \\
\hline 7. Grant's Tomb & $254 \pm 26$ & $237 \pm 3$ & 11 & $294 \pm 8$ & 4.3 & 97.6 \\
\hline 8. Governor's Island & $239 \pm 26$ & $228 \pm 2$ & 11 & $92 \pm 8$ & 4.6 & 100.0 \\
\hline 9. Verrazano Bridge & $206 \pm 17$ & $196 \pm 2$ & 11 & $65 \pm 2$ & 5.6 & 100.5 \\
\hline 10. Sandy Hook & $176 \pm 26$ & $171 \pm 10$ & 8 & $107 \pm 3$ & 4.6 & 101.7 \\
\hline
\end{tabular}


indirectly in each DAPI-stained sample by measuring 200 randomly selected cells with an ocular micrometer and placing them in 1 of 7 size classes. Mean cell volume was calculated from dimensions and simple geometry and carbon biomass was estimated using a conversion factor of $3.50 \times 10^{-13} \mathrm{~g} \mathrm{C} \mathrm{m}^{-3}$ (Bratbak 1993).

Bacterial production. BNP was determined by measuring ${ }^{3} \mathrm{H}$-leucine incorporation into protein (Kirchman 1993). Briefly, at each station $100 \mathrm{ml}$ whole water samples were placed in acid-washed $125 \mathrm{ml}$ polyethylene bottles and immediately spiked with ${ }^{3} \mathrm{H}$-leucine (10 nM final conc.; $\mathrm{L}-\left(4,5-{ }^{3} \mathrm{H}(\mathrm{N})\right)-\mathrm{leu} ; 52 \mathrm{Ci} \mathrm{mmol}^{-1}$; NET 135H, Dupont NEN Products). Samples were placed in an on-deck water bath for $8 \mathrm{~h}$ and maintained at ambient temperature in total darkness, then fixed with cold trichloroacetic acid (TCA; 5\% final conc.). Acid-fixed samples were refrigerated until processing for radiotracer incorporation into protein immediately after the cruise. After heating triplicate $20 \mathrm{ml}$ subsamples at $80^{\circ} \mathrm{C}$ for $15 \mathrm{~min}$, protein precipitates were captured on $0.22 \mu \mathrm{m}$ cellulosic filters (Micron Separations, Inc., Westboro, MA, USA), rinsed with cold 5\% TCA twice, and followed by 3 cold $80 \%$ ethyl alcohol (EtOH) rinses according to standard protocols (Kirchman 1993). Filters were dissolved with $0.5 \mathrm{ml}$ ethyl acetate in scintillation vials and then radioassayed in Hionic-fluor (Packard Co.). Filter blanks were determined from samples that were fixed with $5 \%$ TCA (final conc.) immediately after ${ }^{3} \mathrm{H}$-leucine was added. BNP was calculated as described by Kirchman (1993) using a conversion factor of $3.1 \mathrm{~kg} \mathrm{C} \mathrm{mol}^{-1}$ of leucine incorporated and specific growth rates $(\mu)$ were derived using biomass (B) estimates described above and the logistic growth equation $(\mu=\ln (\mathrm{B}+$ $\mathrm{BNP} / \mathrm{B}) / t$ ), where $t=$ time.

Time courses of bacterial incorporation of ${ }^{3} \mathrm{H}$-leucine were carried out in the laboratory immediately after the cruise with samples from Stns 1 and 10 (salinity end-members). Whole water samples (2.5 l) were maintained at ambient temperature $\left(-5^{\circ} \mathrm{C}\right)$ and returned to the laboratory. Time courses ( 0 to $24 \mathrm{~h}$ ) were performed at $5^{\circ} \mathrm{C}$ using the protocols described above, withdrawing duplicate $20 \mathrm{ml}$ subsamples at each timepoint from initial samples of $220 \mathrm{ml}$.

\section{RESULTS AND DISCUSSION}

\section{Size-fractionated organic carbon concentrations}

Concentrations of organic carbon in the different size-fractions, as well as salinities, chlorophyll a, water temperature and suspended particulate matter, are presented in Tables $1 \& 2$. Concentrations of total DOC varied from 176 to $306 \mu \mathrm{M}$, similar to levels reported for other temperate estuaries, such as the Delaware Estuary (166 to $450 \mu \mathrm{M}_{\text {; }}$ Sharp et al. 1993), the Peconic River estuary $(90$ to $520 \mu \mathrm{M}$; Breuer et al. 1999) and the Mississippi River system ( 88 to $345 \mu \mathrm{M}$; Gardner et al. 1994). However, DOC levels measured along the salinity gradient of the Hudson River estuary were considerably lower than those measured in other estuarine systems in which the rivers drain a more forested watershed, such as the Amazon River system (250 to $1000 \mu \mathrm{M}$; Richey et al. 1990, Benner \& Hedges 1993) and the Ochlockonee River estuary (200 to $1500 \mu \mathrm{M}$; Powell et al. 1996).

The distribution of organic carbon among the operationally defined size classes indicated that HMW (>10 kDa) carbon accounted for $<10 \%$ of the total dissolved carbon in the estuary during our sampling (Table 1). The predominance of LMWOC has also been reported in other studies using the same $(10 \mathrm{kDa})$ molecular weight cut-off (Whitehouse et al. 1989, Guo et al. 1994, Dai et al. 1995, Powell et al. 1996).
Table 2. Concentrations of suspended particulate matter (SPM), phytoplankton biomass (chl a). salinity, and temperature measured in surface waters along the Hudson River estuary during April 3 to 5, 1996

\begin{tabular}{|lcccc|}
\hline Location & $\begin{array}{c}\text { SPM } \\
\left(\mathrm{mg} \mathrm{l}^{-1}\right)\end{array}$ & $\begin{array}{c}\text { Chl a } \\
\left(\mu \mathrm{I} \mathrm{I}^{-1}\right)\end{array}$ & $\begin{array}{c}\text { Salinity } \\
(\mathrm{ppt})\end{array}$ & $\begin{array}{c}\text { Temperature } \\
\left({ }^{\circ} \mathrm{C}\right)\end{array}$ \\
\hline 1. Newburgh Bridge & 27.7 & 0.50 & 0.12 & 5.29 \\
2. Foundry Cove & 18.8 & 0.45 & 0.82 & 5.11 \\
3. Haverstraw Bay & 13.2 & 0.30 & 4.03 & 5.38 \\
4. Piermont & 23.3 & 0.43 & 5.95 & 5.50 \\
5. Yonkers & 30.7 & 0.96 & 8.18 & 5.70 \\
6. G.W. Bridge & 40.4 & 1.70 & 10.51 & 6.40 \\
7. Grant's Tomb & 219 & 1.03 & 11.12 & 6.10 \\
8. Governor's Island & 26.1 & 7.73 & 22.97 & 5.80 \\
9. Verrazano Bridge & 5.23 & 9.1 .2 & 23.52 & 5.60 \\
10. Sandy Hook & 4.50 & 28.8 & 26.53 & 5.30 \\
\hline
\end{tabular}

\section{Nonconservative distributions of size- fractionated organic carbon}

The contrasting distributions of the particulate, dissolved, LMW and HMW organic carbon as a function of salinity suggest that these fractions are cycled differently in the lower Hudson River estuary (Fig. 2). For example, the nonconservative excess, relative to ideal dilution of river and seawater, observed for the DOC and LMW fractions (Fig. 2a,b) contrasts with extensive removal in the HMWOC pool detected in the low salinity region of the estuary (Fig. 2c). Estuarine mixing appears to have no effect on the distribution of POC 

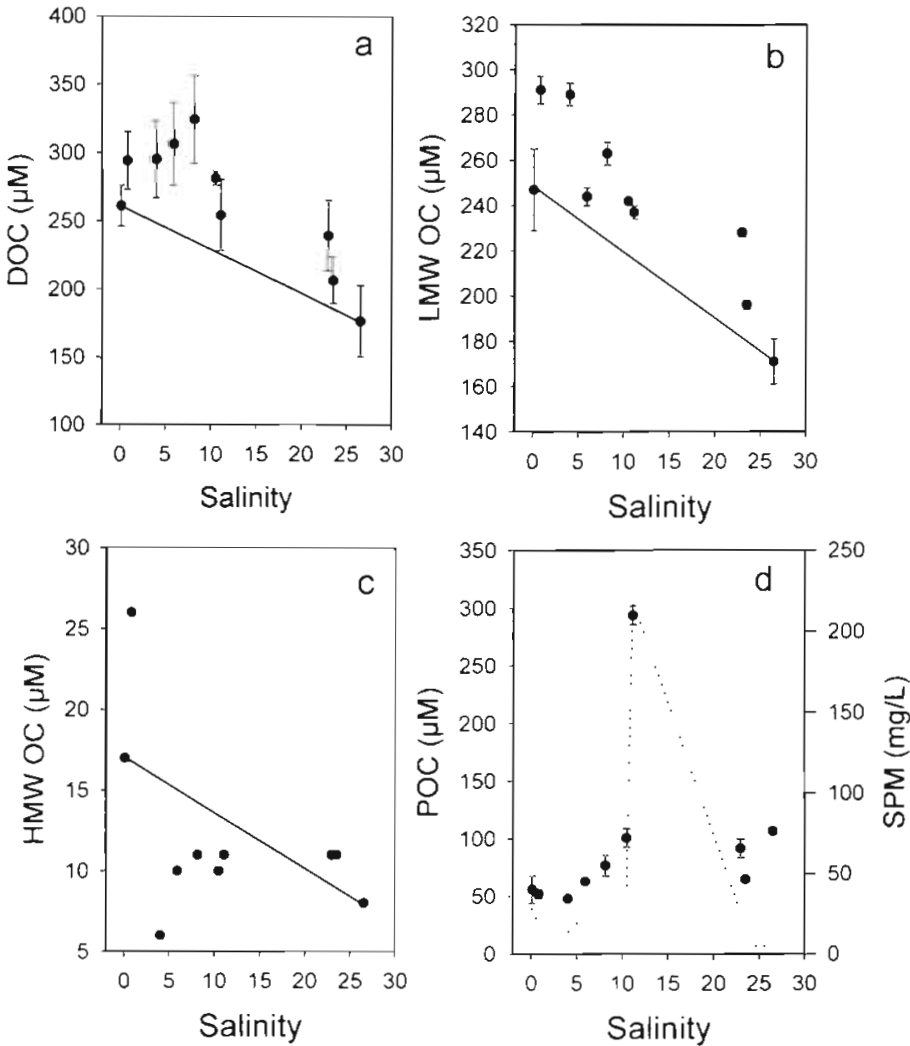

Fig. 2. Total dissolved (a) (DOC) $(<0.45 \mu \mathrm{m})$, (b) LMWOC $(<10 \mathrm{kDa})$, (c) HMWOC (10 kDa $-0.45 \mu \mathrm{m})$ and (d) particulate organic carbon (POC) concentrations versus salinity in the Hudson River estuary. Error bars represent \pm 1 SD of the mean of triplicate analyses. The solid line represents conservative mixing of river water with seawater and the dotted line indicates the total suspended solid distribution

(Fig. 2d). This fraction covaries with the concentrations of total suspended particulate matter (Fig. 2d), as reported for upriver (Findlay et al. 1991a) and for the Mississippi River system (Trefry et al. 1994). The turbidity maximum observed at Stn 7 (salinity $=11$ ) is commonly observed in that part of the estuary (Bokuniewicz 1996). The sediment resuspension in this region is the result of a salt-water front, tidally modulated and bathymetrically controlled (Bokuniewicz 1996).

The nonconservative removal of HMWOC in the low $(<12)$ salinity region of the Hudson (Fig. 2c) is also similar to that reported for humic acids in other estuaries (Fox 1983), suggesting that the HMWOC behaves like humic acids, even if not predominantly composed of those substances. However, the distribution of the HMWOC in the high (>22) salinity region of the estuary appears to be conservative (Fig. 2c). These 2 contrasting behaviors of the HMWOC pool observed along the salinity gradient of the estuary indicate that the sources and/or types of riverine and marine HMWOC may be distinct. The high levels of chlorophyll a ( 8 to
$29 \mathrm{\mu g} \mathrm{l}^{-1}$; Table 2) measured in the marine region of the estuary suggest that the HMWOC could be derived from phytoplankton through a variety of processes. This hypothesis is consistent with the documented release of HMW exudates by phytoplankton in coastal environments (Kepkay et al. 1993, Niven et al. 1995).

In contrast to the coupling of DOC and HMWOC observed elsewhere in coastal waters (Guo et al. 1995), the distinct distributions of HMWOC, DOC and POC pools (Fig. 2), i.e. absence of any correlation among these pools along the Hudson River estuary, suggest that the amount of HMWOC is not simply a function of the amount of DOC or POC but probably relates to the quality of these materials. The high proportion of LMWOC indicates that this pool is responsible for the nonconservative excess in the DOC fraction. Moreover, any additional non-POC inputs to the estuary were either primarily LMWOC or rapidly transformed into LMWOC through degradative processes. This nonconservative DOC distribution contrasts with the conservative behavior of riverine DOM reported in other estuaries (Mantoura \& Woodward 1983, Dai et al. 1995) and even reported for the tidal freshwater reach of the Hudson River (Findlay et al. 1991a).

The obvious explanation for DOC excesses at intermediate salinities is the anthropogenic contributions from the heavily urbanized New York-New Jersey watershed, such as sewage and surface run-off. However, the geographical distribution of DOC indicates that deviation from the theoretical 2 end-member mixing relationship (Fig. 2a) might be due to additional processes. Although this estuary receives approximately $100 \mathrm{~m}^{3} \mathrm{~s}^{-1}$ of sewage (Brosnan \& O'Shea 1996), DOC levels were highest about $15 \mathrm{~km}$ upriver from the largest Manhattan sewage treatment plant (STP) outfall in the Hudson (North River STP). Furthermore, DOC levels were consistently high at all stations upriver, and steadily diminished from Stn 5 to NY Harbor (Fig. 3).

In contrast, dissolved phosphate, which is considered a tracer of sewage in the Hudson River estuary (Clark et al. 1992), was consistently high from the station with the highest DOC levels (Stn 5) down to the confluence of the East River and the NY Harbor (Stn 8) which exhibited only moderate DOC levels (Fig. 3). Differences in distributions of phosphate and DOC suggest that DOC levels were not strongly controlled by sewage input at this time of year. Obviously, this and other anthropogenic sources of DOC cannot be totally discounted. Because sampling was conducted in April 1996 after a winter of record snow accumulation, the DOC excesses could be related to the high run-off volume of melt waters, rich in terrigenous carbon. The importance of external loadings of organic matter from tributaries to the carbon budget of the upper Hudson 
River has been suggested previously (Howarth et al. 1992). However, the nonconservative behavior of DOC observed in our area of study compared to the conservative mixing reported upriver by Findlay et al. (1991a) suggests that biogeochemical processes controlling the cycling of organic matter vary in different reaches of the same river. This is further demonstrated by observations on bacterial dynamics presented below.

\section{Bacterial abundance and production}

Bacterial abundances along the Hudson River estuary varied from 5 to $16 \times 10^{8}$ cells $1^{-1}$ (Table 3 ). This range was consistent with the low end of ranges reported in other U.S. east coast estuaries, such as the Rhode River estuary $\left(3.0 \times 10^{8}\right.$ cells $\mathrm{l}^{-1}$; Rublee et al. 1984), the Delaware River estuary $\left(6.5\right.$ to $10 \times 10^{8}$ cells $\mathrm{l}^{-1}$; Coffin \& Sharp 1987, Hoch \& Kirchman 1993) and in Massachusetts, USA, salt marsh estuaries $\left(7 \times 10^{8}\right.$ cells $l^{-1}$; Wright \& Coffin 1983). The average cell density in the Hudson

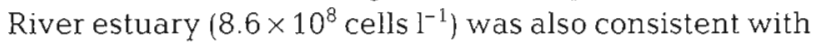
minimum cell counts $\left(10 \times 10^{8}\right.$ cells $\mathrm{l}^{-1}$; Findlay et al. $1991 b)$ measured in the tidal freshwater Hudson River in early spring.

Bacterial carbon production varied from 3.7 to $28.7 \mu \mathrm{g} \mathrm{Cl}^{-1} \mathrm{~d}^{-1}$ (Table 3). The average BNP measured

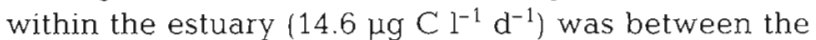
high annual average reported for the freshwater section of Hudson River $\left(246 \mu \mathrm{g} \mathrm{C} \mathrm{l}^{-1} \mathrm{~d}^{-1}\right.$; Findlay et al. $1991 \mathrm{~b})$ and the relatively low production detected in the Hudson River plume through the New York Bight (1.6 to $2.4 \mu \mathrm{g} \mathrm{C} \mathrm{l}^{-1} \mathrm{~d}^{-1}$; Ducklow \& Kirchman 1983). Because bacterial abundances and production are usually positively correlated with temperature (Wright \& Coffin 1983, Findlay et al. 1991a), our relatively low bacterial abundance and productivity estimates were presumably depressed due to the low water temperatures (range $=5.1$ to $6.4^{\circ} \mathrm{C}$ ) prevailing during our sampling. Higher bacterial concentrations and production are likely to occur in the summer months in the Hudson River when water temperatures can reach $25^{\circ} \mathrm{C}$ (Findlay et al. 1991 b, Ashizawa \& Cole 1994).

\section{Spatial gradients in bacterial dynamics}

While previous studies in the freshwater tidal region of the Hudson River estuary did not find any spatial trends in bacterial concentrations or production (Findlay et al. 1991b), our results showed a strong spatial gradient for both variables within the lower portion of the estuary (Fig. 4A,B). Both bacterial abundances and production increased with salinity, being lowest at the riverine end-member and highest in the upper Bay/NY Harbor region. With the exception of 1 station in the upper Bay (Stn 8), bacterial concentrations increased linearly with salinity, suggesting conservative mixing of bacteria and/or their growth substrates (Fig. 4A). The highest bacterial abundances and production were measured at Stn 8, near the confluence of the East River and the NY Harbor, suggesting additional input of cells or labile OC from the East River. Higher bacterial activity at this station is consistent with the facts that the East River's shorelines are more densely urbanized than those of the Hudson and it receives waters from numerous STP outfalls and western Long Island Sound. The conservative bacterial distribution rela-

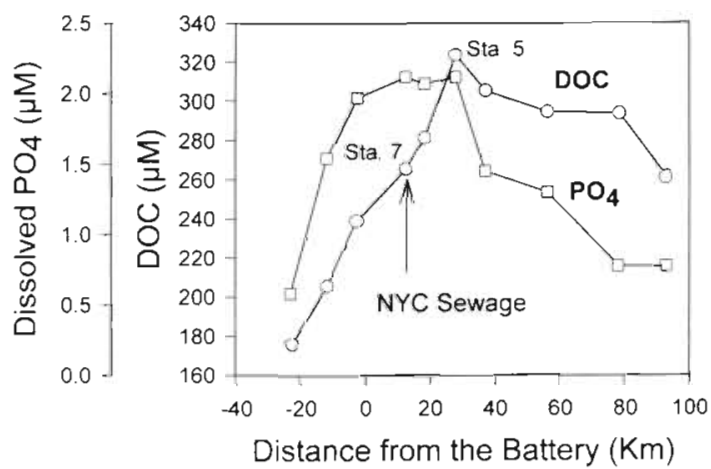

Fig. 3. Geographical distribution of DOC $(O)$ and phosphate (口) along the Hudson River estuary. Locations are referred to by the axial distance, kilometers upstream (+) and downstream (-) from the Battery at the southern tip of Manhattan Island. The arrow indicates the location of the North River sewage treatment plant

Table 3. Bacterial abundances, production and specific growth rate measured in surface waters of the Hudson River estuary in April 1996. Bacterial abundances reported as the mean \pm 1 SD of counts from 10 fields on a single filter. Bacterial production and growth reported as the mean \pm 1 SD of triplicate analyses

\begin{tabular}{|c|c|c|c|}
\hline Location & $\begin{array}{c}\text { Bacterial } \\
\text { abundance } \\
\left(10^{8} \text { cell } \mathrm{I}^{-1}\right)\end{array}$ & $\begin{array}{c}\text { Bacterial } \\
\text { production } \\
\left(\mu g \mathrm{Cl}^{-1} \mathrm{~d}^{-1}\right)\end{array}$ & $\begin{array}{c}\text { Specific } \\
\text { growth rate } \\
\qquad\left(\mathrm{d}^{-1}\right)\end{array}$ \\
\hline 1. Newburgh Bridge & $5.35 \pm 0.36$ & $4.04 \pm 0.95$ & $0.12 \pm 0.033$ \\
\hline 2. Foundry Cove & $5.03 \pm 0.37$ & $5.38 \pm 0.45$ & $0.16 \pm 0.011$ \\
\hline 3. Haverstraw Bay & $6.68 \pm 0.66$ & $3.37 \pm 0.03$ & $0.09 \pm 0.00$ \\
\hline 4. Piermont & $6.71 \pm 0.40$ & $8.01 \pm 0.13$ & $0.24 \pm 0.00$ \\
\hline 5. Yonkers & $7.12 \pm 0.43$ & $17.28 \pm 1.90$ & $0.61 \pm 0.07$ \\
\hline 6. G.W. Bridge & $7.98 \pm 0.37$ & $10.06 \pm 0.75$ & $0.35 \pm 0.03$ \\
\hline 7. Grant's Tomb & $6.63 \pm 0.28$ & $1.9 .85 \pm 1.56$ & $0.66 \pm 0.05$ \\
\hline 8. Governor's Islannd & $16.00 \pm 0.68$ & $28.68 \pm 0.79$ & $0.54 \pm 0.02$ \\
\hline 9. Verrazano Bridge & $12.25 \pm 0.70$ & $26.05 \pm 0.45$ & $0.43 \pm 0.01$ \\
\hline 10. Sandy Hook & $11.69 \pm 0.60$ & $23.03 \pm 1.70$ & $0.28 \pm 0.02$ \\
\hline
\end{tabular}


tive to salinity in the Hudson River estuary reported here is consistent with the distribution pattern observed in several other estuaries (e.g. Palumbo \& Ferguson 1978, Wright \& Coffin 1983). Even though a conservative distribution might be interpreted as indicating that bacterial communities are only affected by mixing, we demonstrate below that this is not the case for our observations.

Evidence for differential responses of freshwater and estuarine bacterial communities among stations is provided by examining BNP normalized to bacterial abundance or community-specific growth rates. The underlying assumption of this calculation is that all cells utilized the radiotracer and grew at the same rate, which is certainly untrue. As observed elsewhere, probably only a subset of populations were actively growing on available substrates while other populations were relatively dormant (Karner \& Fuhrman 1997). Consequently, this approach provides a conservative estimate of bacterial growth rates. Even though total BNP was relatively coherent with salinity (Fig. 4B), specific growth rates varied unpredictably $\left(r^{2}=0.47, p<0.17\right)$ with salinity (Fig. 5). Growth rates at the riverine end tended to be lower than at the marine end, but were highest at 2 intermediate salini-
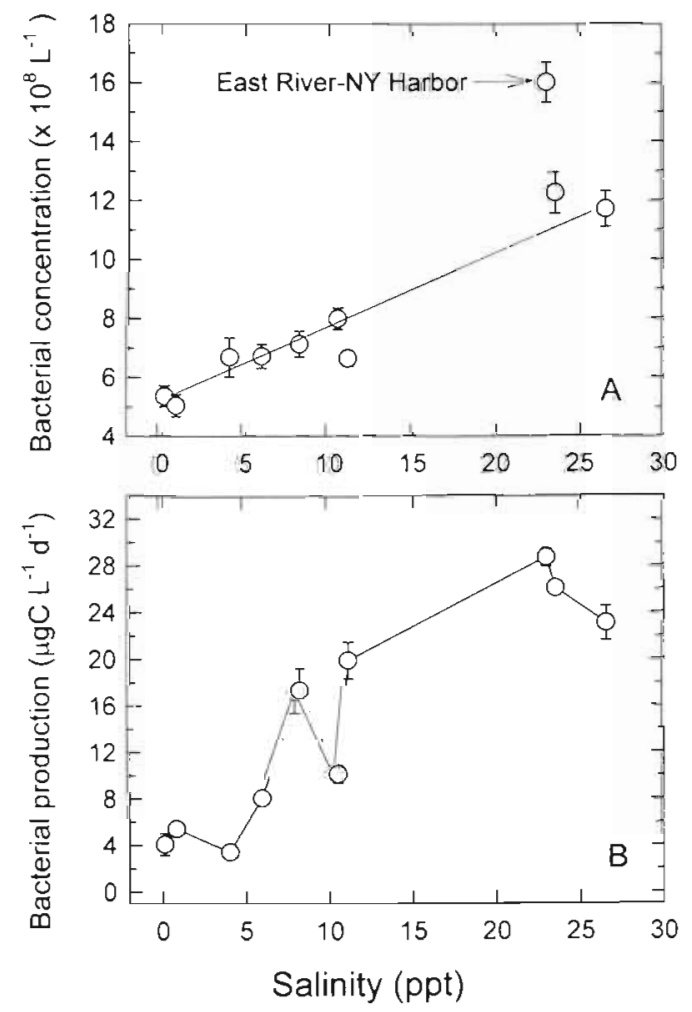

Fig. 4. Bacterial (A) abundance and (B) production as functions of salinity in the Hudson River estuary. Error bars represent \pm 1 SD of the mean; absence indicates error is smaller than symbol

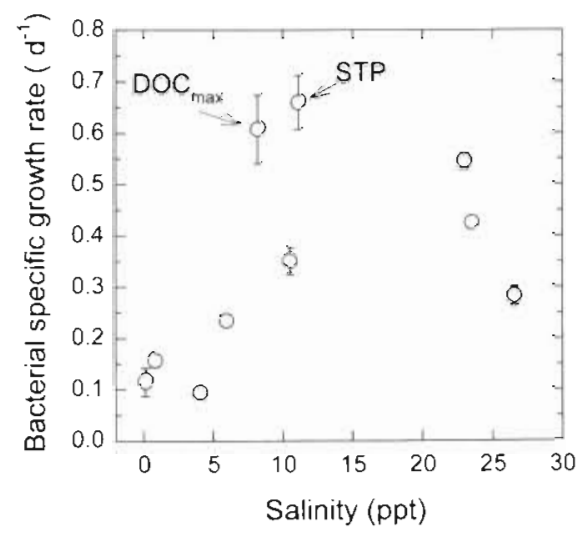

Fig. 5. Variance in bacterial specific growth rates along the salinity gradient. $D O C_{\max }$ and STP represent stations coinciding with highest observed DOC concentration and the North River sewage treatment plant (STP) outfall

ties, Stns 5 and 7, which coincided with the DOC maximum (Fig. 3) and the North River STP outfall, respectively. These observations demonstrate that controls on bacterial production are heterogeneous along the salinity gradient and may depend on the interplay of in situ primary production, allochthonous input of labile OM (watershed and point sources), temperature and salinity as it affects OM partitioning. These controls are evaluated below.

\section{Factors controlling bacterial dynamics in the lower Hudson River estuary}

Phytoplankton biomass

Unlike Chin-Leo \& Benner's (1992) study of the Mississippi River, few estuarine and riverine studies have reported discernible coupling between bacterioplankton and phytoplankton dynamics, presumably as a consequence of the high allochthonous loadings of bacterial substrates and strong light attenuations in these systems. In the present study, however, bacterial abundances within the lower Hudson River estuary were positively correlated $\left(r^{2}=0,70\right.$; Fig. 6a) with algal standing stocks during this April cruise (chlorophyll a [chl a $]_{i}$ Fig. 6a). The potential importance of phytoplankton to bacterial dynamics is further supported by the covariance of BNP and chl a $\left(\mathrm{r}^{2}=0.75\right.$; Fig. 6b). These trends are in stark contrast to the absence of any discernible relationship between BNP and phytoplankton biomass distributions reported previously for the tidal freshwater reach of the Hudson (Findlay et al. 1991b), the Hudson River plume in the New York Bight (Ducklow \& Kirchman 1983), the Chesapeake Bay (Ducklow \& Shiah 1993), and the Delaware River estu- 
ary (Coffin \& Sharp 1987, Hoch \& Kirchman 1993). The apparent coherence between phytoplankton and bacterioplankton suggests that both communities are either trophically linked or under similar physiological constraints.

The similarity between phytoplankton-bacterioplankton covariance we observed and those reported in Cole et al.'s (1988) cross-ecosystem study (Fig. 6b) appears to confirm that bacterioplankton activity is controlled, at least in part, by substrates derived from phytoplankton. Therefore, the saline portion of the Hudson River estuary may have conformed, to some extent, to other autotrophically dominated marine and freshwater systems during this sampling. We note that all our data points are significantly higher than Cole et al.'s (1988) regression line (Fig. 6b), which was derived from 70 net autotrophic systems in which BNP was $20 \%$ of net primary production on average. Therefore, either the bacterial communities in our study were significantly more efficient than those in the 70 studies incorporated into Cole et al.'s (1988) model or OC supplied directly or indirectly from phytoplankton was insufficient to support all BNP observed. The first explanation seems implausible based on recent observations from many systems that bacterioplankton exhibit average growth effciencies of approximately 25\% (del Giorgio et al. 1997). Therefore, we conclude that carbon subsidies from other sources are necessary to support the observed BNP.

\section{High molecular weight organic carbon (HMWOC)}

Within the Hudson estuary, variance in bacterial growth rates strongly correlates $\left(\mathrm{r}^{2}=0.79\right.$; excluding riverine outliers) with variance in HMWOC (Fig. 7a), while not correlating at all with distributions of LMWOC (Fig. 7b), total DOC or POC pools (not presented). In fact, HMWOC distributions explained the observed variance in bacterial growth far better than any other measured 'independent' variable, if we ignore Stns 1 and 2 (Fig. 7). We note that covariance between these 2 variables does not prove the existence of a direct relationship nor did we measure bacterial growth rates directly in the size-fractionated samples. Nonetheless, we speculate that bacterioplankton preferentially utilize HMWOC over LMWOC. Our hypothesis is founded upon previous reports of rapid HMWOC turnover by bacterioplankton in laboratory and field studies from several environments (Travnik 1990, Kepkay et al. 1993, Hedges et al. 1994, Moran \& Hodson 1994, Amon \& Benner 1996) as well as our observed depletions of HMWOC along the gradient.

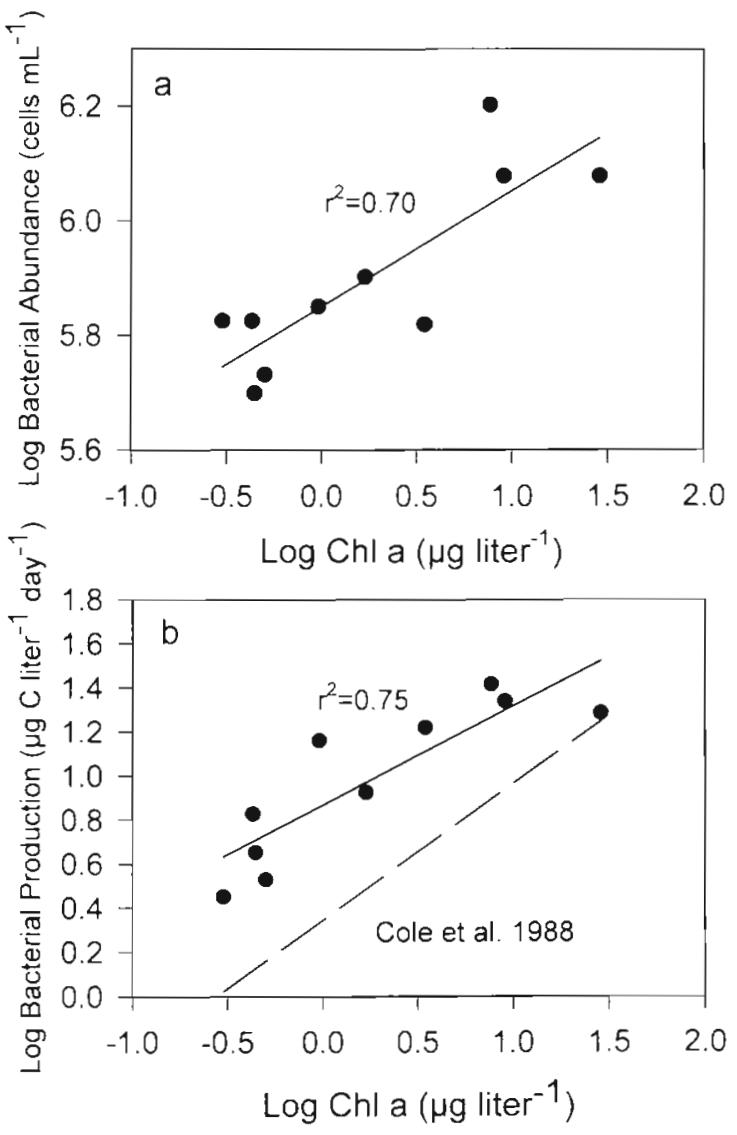

Fig. 6. Relationship between bacterial (a) abundance and (b) production with chlorophyll a concentrations in the lower Hudson River estuary. Dashed line represents the bacterial production predicted from chl a concentrations using the relationship reported by Cole et al. (1988) in a cross-system study

Temperature

Water temperature is known to influence bacterial activity in estuaries (Wright \& Coffin 1983, Coffin \& Sharp 1987. Findlay et al. 1991b, Hoch \& Kirchman 1993), but we believe that its effects in this study were minimal. In April, surface water temperature was relatively constant, varying from $5.1^{\circ} \mathrm{C}$ upriver to $6.4^{\circ} \mathrm{C}$ in the G.W. Bridge (Table 2). Assuming a $Q_{10}$ of between 2 and 3 , this temperature excursion would accelerate bacterial metabolism by factors of 1.26 to 1.39 at most along the gradient. We observed BNP and specific growth rates increasing along the gradient by factors of 8.5 and 7.3 , respectively. Temperature effects can only account for 14 to $19 \%$ of the ranges observed for bacterial activity. Therefore, most of the observed variation in bacterial metabolism and composition must be ascribed to responses of different bacterial populations to availability of labile substrate. 

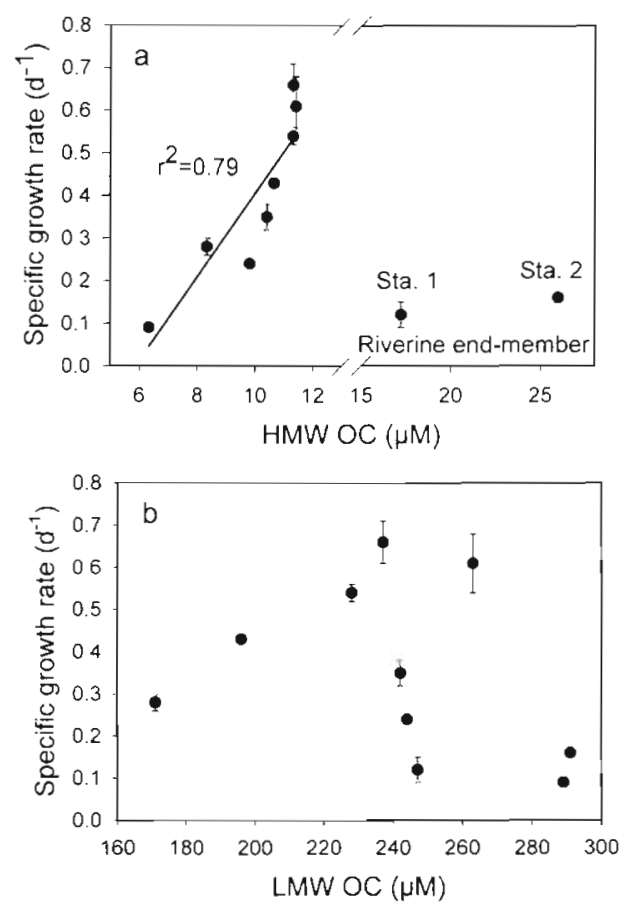

Fig. 7. Relationship between bacterial specific growth rates and concentrations of: (a) HMWOC and (b) LMWOC. Specific growth rate was estimated using biomass $(B)$ and bacterial net production (BNP) estimates and the logistic growth equation $(=\ln (B+B N P / B) / t)$, where $t=$ time

\section{Bacterial-substrate interactions}

Enrichment of HMWOC alone appeared to be insufficient to stimulate growth in the freshwater section of the estuary (Stns 1 and 2), where specific rates were relatively low despite high concentrations of HMWOC (Table 3, Fig. 7a). Low rates of BNP measured at the riverine stations could be attributed to lower bacterial abundances. However, specific growth rates, which are production rates normalized by observed biomass, were also anomalously low at Stns 1 and 2 (Fig. 7). Our results suggest that the lability of organic matter varied along the gradient or that freshwater and estuarine bacterial communities responded differently to substrate availability, i.e. copiotrophs versus oligotrophs. The first alternative was not addressed experimentally but certainly seems plausible for a dynamic pool with many potential sources. The second alternative is explored below.

Differences in responses of upstream and downstream bacterial communities to labile substrate availability are illustrated by the ${ }^{3} \mathrm{H}$-leucine time course experiments performed on samples from Stns 1 and 10 (Fig. 8). Three facts are evident from the time course experiments; ${ }^{3} \mathrm{H}$-leucine incorporation was linear for the first $12 \mathrm{~h}$ (field end-point experiments had $8 \mathrm{~h}$ durations), initial rates of ${ }^{3} \mathrm{H}$-leucine incorporation at Stn 1 are 1.6 times slower per capita than at Stn 10 and cells at Stn 1 incorporate 1.7 times less ${ }^{3} \mathrm{H}$-leucine after $24 \mathrm{~h}$ (Fig. 8). An undefined portion of the differences observed in cellspecific ${ }^{3} \mathrm{H}$-leucine incorporation may be an artifact of the proportion of cells active in amino acid uptake and amino acid pool size. Nonetheless, differences in leucine turnover are even greater when bacterial community size is considered. As an illustration, a first-order model for total ${ }^{3} \mathrm{H}$-leucine incorporation $\left(\mathrm{Ci} \mathrm{l}^{-1} \mathrm{~d}^{-1}\right)$ was used to derive half-lives $\left(t_{1 / 2}\right)$ of leucine in the environment (and presumably other amino acids utilized by the same bacterial transport mechanisms) and they varied by a factor of $4 ; 6.1$ and $1.5 \mathrm{~d}$ at Stns 1 and 10, respectively. These are conservative turnover times because respiration of the labeled substrate was not assessed, but is assumed to be a minor fraction of uptake (Kirchman 1993).

\section{Geochemical implications of estuarine cycling of $\mathrm{OC}$ by bacterioplankton}

The low concentrations of HMWOC, accounting for $<10 \%$ of the total dissolved pool, suggest that this pool does not play a major role in the mass balance of the total organic carbon budget in the estuary. However, the steep slope and strong coherence between bacterial growth and HMWOC distributions (Fig. 7a) suggest that HMW organics may play a major role in bacterial nutrition. Also, bacterial metabolism may influence the fractionation and composition of the riverine organic carbon delivered to the sea. Assuming an average BNP rate of $9.7 \mu \mathrm{g} \mathrm{Cl}^{-1} \mathrm{~d}^{-1}$ at low and intermediate salinities (Stns 1 to 7; Table 3) and a growth yield efficiency of 21 to $46 \%$ (del Giorgio et al. 1997), bacterial metabolism could potentially decompose 21 to $46 \mu \mathrm{g} \mathrm{C} \mathrm{l}^{-1} \mathrm{~d}^{-1}$, which corresponds to a daily consumption of 14 to $30 \%$ of the average HMWOC concentration at those locations (154 $\mathrm{gg} \mathrm{I}^{-1}$; Table 1). Furthermore, an important fraction of the HMWOC can be attributed to bacterial biomass because $0.45 \mu \mathrm{m}$ filters were employed to exclude particles. With an average cell abundance of

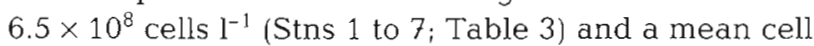
mass of $45 \mathrm{fg} \mathrm{C}$ cell $^{-1}$, bacterial biomass could account for up to $19 \%$ of the average HMWOC concentration measured in this region (29 $\mu \mathrm{g} \mathrm{C}^{-1} / 154 \mu \mathrm{g} \mathrm{C} \mathrm{l}^{-1}$ ).

The anomalously low bacterial activity observed with concomitantly high HMWOC concentrations at riverine locations (Stns 1 and 2) and the nonconservative behavior of that size-class of organic carbon in the estuary suggest that this pool varies qualitatively in different regions of the estuary. For example, upstream HMWOC could be dominated by refractory terrige- 


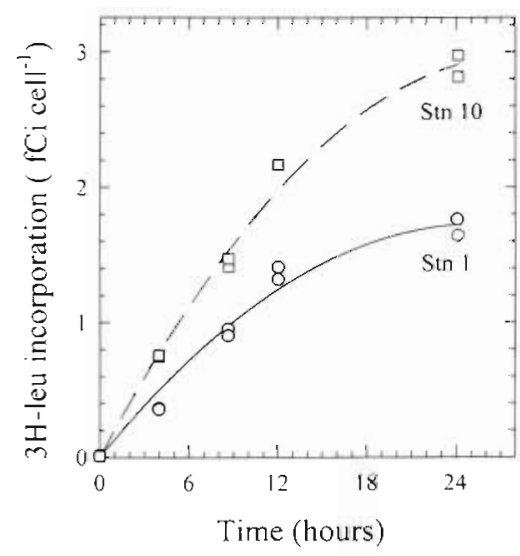

Fig. 8. Time course of ${ }^{3} \mathrm{H}$-leucine incorporation into protein, normalized by cell concentration, $n$. At Stn $1, n=5.4 \times 10^{8}$ cells $\mathrm{l}^{-1}$, community uptake rate constant, $k=0.12 \mathrm{~d}^{-1}$, and the leucine half-life, $t_{1 / 2}=6.1 \mathrm{~d}$. At Stn $10, \mathrm{n}=12.0 \times 10^{8}$ cells l$^{-1}$, $k=0.46 \mathrm{~d}^{-1}$, and $t_{1 / 2}=1.5 \mathrm{~d}$

nous materials, e.g. humic and fulvic acids, which may flocculate out as salinities increase, whereas downstream HMWOC may originate from autochthonous or other allochthonous sources, such as sewage, and be less refractory in composition. The composition and lability of HMWOC along this reach of the Hudson estuary can not be assessed with existing data nor are there any direct methods for such determinations. However, while carbon and bacterial dynamics in this estuary must certainly vary seasonally with flow conditions, nutrient inputs, and temperature, our results indicate that HMWOC is a very important component of the DOC despite its small contribution to the total carbon budget. Therefore, our ongoing research is employing a variety of indirect methods (e.g. hydrolytic enzyme activity, bacterial oxygen demand, and radiotracer studies) to better assess the importance of HMW material in carbon cycling throughout the year. Finally, our results also suggest that trophic relationships and organic carbon cycling may vary significantly in different reaches of this river. Specifically, that, unlike the upper reaches of the Hudson. River, bacterioplankton production in the estuarine portion may be coupled to in situ primary production for at least some portion of the year.

Acknowledgements. The authors are grateful to E. Breuer, $C$ Gobler, M. Lee, E. Mariotti, J. Nichols, K. Roberts, and M. Yang for sampling and analytical support. Organic carbon analyses were performed by D. Hirschberg of the MSRC Analytical Facility. Research was supported, in part, by a grant awarded to S.A.S.W. by the Hudson River Foundation (HRF grant no. 010/95A). Marine Sciences Research Center (SUNY Stony Brook) contribution number 1156.

\section{LITERATURE CITED}

Aminot A, El-Sayed M, Kerouel R (1990) Fate of natural and anthropogenic dissolved organic carbon in the macrotidal Elorn estuary (France). Mar Chem 29:255-275

Amon RMW, Benner R (1996) Bacterial utilization of different size classes of dissolved organic matter. Limnol Oceanogr 41:41-51

Ashizawa D. Cole JJ (1994) Long-term temperature trends of the Hudson River: a study of the historical data. Estuaries $17: 166-171$

Benner R, Hedges JI (1993) A test of the accuracy of freshwater DOC measurements by high-temperature catalytic oxidation and UV-promoted persulfate oxidation. Mar Chem. 41:161-165

Benner R, Opsahl S, Chin-Leo G, Richey JE, Forsberg B (1995) Bacterial carbon metabolism in the Amazon River system. Limnol Oceangr 40:1262-1270

Bokuniewicz H (1996) Building the turbidity maximum in the Hudson River estuary. Mar Sci Res Center Special Rep 115, Ref. 96-06

Bratbak G (1993) Microscope methods for measuring bacterial biovolume: epifluorescence microscopy, scanning electron microscopy, and transmission electron microscopy. In: Kemp PF, Sherr BF, Sherr EB, Cole JJ (eds) Handbook of methods in aquatic microbial ecology. Lewis, Boca Raton, p 309-317

Breuer E, Sañudo-Wilhelmy SA, Aller RC (1999) Distributions of trace metals and dissolved organic carbon in an estuary with restricted river flow: the Peconics. Estuaries (in press)

Brosnan TM, O'Shea ML (1996) Sewage abatement and coliform bacteria trends in the lover Hudson-Raritan Estuary since passage of the Clean Water Act. Water Environ Res $68: 25-35$

Buesseler KO, Bauer JE, Chen RF, Eglinton TI, Gustafsson O Landing W, Mopper K. Moran SB, Santschi PH, Vernon Clark R, WelJs ML (1996) An intercomparison of cross-flow filtration techniques used for sampling marine colloids overview and organic carbon results. Mar Chem 55:1-31

Chin-Leo G, Benner R (1992) Enhanced bacterioplankton production and respiration at intermediate salinities in the Mississippi River plume. Mar Ecol Prog Ser 87:87-103

Clark JF, Simpson HJ, Bopp RF, Deck B (1992) Geochemistry and loading history of phosphate and silicate in the Hudson Estuary. Estuar Coast Shelf Sci 34:213-233

Coffin RB, Sharp JH (1987) Microbial trophodynamics in the Delaware estuary. Mar Ecol Prog Ser 41:253-266

Cole JJ, Findlay S, Pace ML (1988) BNP in fresh and saltwater ecosystems: a cross-system overview. Mar Ecol Prog Ser $43: 1-10$

Connoliy JP, Coffin RB (1995) A model of carbon cycling in the planktonic food web. J Environ Eng 121:682-690

Dai M, Martin JM. Cauwet G (1995) The significant role of colloids in the transport and transformation of organic carbon and associated trace metals $(\mathrm{Cd}, \mathrm{Cu}$, and $: i$ i) in the Rhone delta (France). Mar Chem 51:159-175

de] Giorgio PA, Cole JJ, Cimbleris A (1997) Respiration rates in bacteria exceed phytoplankton production in unproductive aquatic systems. Nature 385:148-151

Ducklow H. Kirchman DL (1983) Bacterial dynamics and distribution during a spring diatom bloom in the Hudson River plume. J Plankton Res 5:333-355

Ducklow HW, Shiah F (1993) Bacterial production in estuaries. In: Ford $\mathrm{T}$ (ed) Aquatic microbiology: an ecological approach, Vol 11. Blackwell Scientific Publishers, New York, p 261-288

Findlay S, Pace ML, Lints D (1991a) Variability and transport 
of suspended sediment, particulate and dissolved organic carbon in the tidal freshwater Hudson River. Biogeochem 12:149-169

Findlay S, Pace ML, Lints D, Cole JJ, Caraco NF, Peierls B (1991b) Weak coupling of bacterial and algal production in a heterotrophic ecosystem: the Hudson River estuary Limnol Oceanogr 36:268-278

Findlay S, Pace ML, Lints D, Howe K (1992) Bacterial metabolism of organic carbon in the tidal freshwater Hudson Estuary. Mar Ecol Prog Ser 89:147-153

Fox LE (1983) The removal of dissolved humic acid during estuarine mixing. Estuar Coast Shelf Sci 16:431-440

Gardner WS, Benner R, Chin-Leo G, Cotner JB Jr, Eadie BJ, Cavaletto JF, Lansing MB (1994) Mineralization of organic material and bacterial dynamics in Mississippi River plume water. Estuaries 17:816-828

Guo L, Coleman CH, Santschi PH (1994) The distribution of colloidal and dissolved organic carbon in the Gulf of Mexico. Mar Chem 45:105-119

Guo L, Santschi PH, Warnken KW (1995) Dynamics of dissolved organic carbon (DOC) in oceanic environments. Limnol Oceanogr 40:1392-1403

Hedges JI, Cowie GL, Richey JE, Quay PD, Benner R, Strom M, Forsberg BR (1994) Origins and processing of organic matter in the Amazon River as indicated by carbohydrates and amino acids. Limnol Oceanogr 39:743-761

Hoch MP, Kirchman DL (1993) Seasonal and inter-annual variability in bacterial production and biomass in a temperate estuary. Mar Ecol Prog Ser 98:283-295

Howarth RW, Marino R, Garritt R, Sherman D (1992) Ecosystem respiration and organic carbon processing in a large, tidally influenced river: the Hudson River. Biogeochem 16: 83-102

Karner M, Fuhrman JA (1997) Determination of active marine bacterioplankton: a comparison of universal 16s rRNA probes, autoradiography, and nucleoid staining. Appl Environ Microbiol 63:1208-1213

Kepkay PE, Niven SHE, Milligan TG (1993) Low molecular weight and colloidal DOC production during a phytoplankton bloom. Mar Ecol Prog Ser 100:233-244

Kirchman DL (1993) Leucine incorporation as a measure of biomass production by heterotrophic bacteria. In: Kemp PF, Sherr BF, Sherr EB, Cole JJ (eds) Handbook of methods in aquatic microbial ecology. Lewis, Boca Raton, p 509-512

Mantoura RFC, Woodward EMS (1983) Conservative behaviour of riverine dissolved organic carbon in the Severn Estuary: chemical and geochemical implications. Geochim Cosmochim Acta 47:1293-1309

Moran MA, Hodson RE (1994) Support of bacterioplankton

Editorial responsibility: Otto Kinne (Editor),

Oldendorf/Luhe, Germany production by dissolved humic substances from three marine environments. Mar Ecol Prog Ser 110:241-247

Niven SHE, Kepkay PE, Boraie A (1995) Colloidal organic carbon and colloidal 234 Th dynamics during a coastal phytoplankton bloom. Mar Ecol Prog Ser 42:257-273

Palumbo AV, Ferguson RL (1978) Distribution of suspended bacteria in the Newport River estuary, North Carolina. Estuar Coast Mar Sci 7:521-529

Porter K, Feig YS (1980)The use of DAPI for identifying and counting aquatic microflora. Limnol Oceanogr 25:943-948

Powell RT, Landing WM, Bauer JE (1996) Colloidal trace metals, organic carbon and nitrogen in a southeastern U.S. estuary. Mar Chem 55:165-176

Richey JE, Hedges Jl, Devol AH, Quay PD, Victoria R, Martinelli L, Forsberg BR (1990) Biogeochemistry of carbon in the Amazon River. Limnol Oceanogr 35:352-371

Rublee PA, Merkel SM, Faust MA, Miklas J (1984) Distribution and activity of bacteria in the headwaters of the Rhode River estuary, Maryland, USA. Microb Ecol 10 243-255

Sañudo-Wilhelmy SA, Rivera-Duarte I, Flegal AR (1996) Distribution of colloidal trace metals in the San Francisco Bay estuary. Geochim Cosmochim Acta 60:4933-4944

Sharp JH, Suzuki Y, Munday WL (1993) A comparison of dissolved organic carbon in North Atlantic Ocean nearshore waters by high temperature combustion and wet chemical oxidation. Mar Chem 41:253-259

Strickland JDH, Parsons TR (1972) A practical handbook of seawater analysis. Bull Fish Res Board Can 167:310

Tranvik LJ (1990) Bacterioplankton growth on fractions of dissolved organic carbon of different molecular weight from humic and clear waters. Appl Environ Microbiol 56: $1672-1677$

Trefry JH, Nelsen TA, Trocine RP, Eadie BJ (1994) Transport of particulate organic carbon by the Mississippi River and its fate in the Gulf of Mexico. Estuaries 17:830-849

Wen LS, Stordal MC, Tang D, Gill PA, Santschi PH (1996) An ultraclean cross-flow ultrafiltration technique for the study of trace metal phase speciation in seawater. Mar Chem 55: $129-152$

Whitehouse BG, MacDonald RW, Iseki $\mathrm{K}$, Yunker MB, McLaughlin FA. (1989) Organic carbon and colloids in the Mackenzie River and Beaufort Sea. Mar Chem 26: $371-378$

Whitehouse BG, Yeats PA, Strain PM (1990) Cross-flow filtration of colloids from aquatic environments. Limnol Oceanogr 35:1368-1375

Wright RT, Coffin RB (1983) Planktonic bacteria in estuaries and coastal. waters of northern Massachusets: spatial and temporal distribution. Mar Ecol Prog Ser 11:205-216

Submitted: June 17, 1998; Accepted: January 25, 1999

Proofs received from author(s): May 10, 1999 